\title{
Audiens Milenial dan Iklan Viral: Kajian Daya Tarik Iklan \#KerenLahirBatin terhadap Brand Image Ramayana Department Store
}

\author{
Hasna Nur Lina \\ | Departemen Ilmu Komunikasi FISIPOL Universitas Gadjah Mada, \\ bisa dihubungi melalui email hasnanrlina@gmail.com \\ Lidwina Mutia Sadasri \\ | Departemen IImu Komunikasi FISIPOL Universitas Gadjah Mada, \\ bisa dihubungi melalui email lidwina.mutia@ugm.ac.id
}

\begin{abstract}
ABSTRAK
Advertising appeals as one of advertising aspects to attract target audiences is significant to be analyzed, furthermore advertisements that audiens consume are excessive day by day. Ramayana Department Store as one of Indonesian mature vendor are catching up with the dynamics by developing advertising appeal that they have. One of the innovative efforts that they done is Ramadan advertising entitled \#KerenLahirBatin that going viral in 2018 with more than 12 million times watched and 9,806 comments until by the end of 2018. This research is focusing on describing the effect of advertising appeals to Ramayana's brand image using survey methods and descriptive analysis technique. Respondents of this study are Indonesian millennial audiences aged 19-34 years with a sample of 100 people obtained through Slovin's formula. Finding shown that advertising appeals that bridged by audience involvement in message processing has a greater and positive influence on the brand image of Ramayana Department Store compared to the direct influence of advertising appeals on the brand image that does not including audience involvement. The advertising appeals, especially emotional appeals, are proven to increase motivation, opportunity, and the ability of the audience to watch as well as understand the ad. The dominance of this emotional appeals results in respondents tend to use peripheral route to process messages. However, the results of the formed brand image of Ramayana are positive and are a combination of functional and emotional aspects that are absorbed simultaneously. Noting that the effects generated through peripheral processing route are usually temporary and the effect of advertising appeals and audience involvement are only 16\%, other aspects of marketing communication efforts are needed in order to strengthen the brand image of Ramayana Department Store.
\end{abstract}

Keywords: advertising appeals, viral advertising, elaboration likelihood model, brand image.

\section{Pendahuluan}

Ramayana Department Store adalah toko eceran berskala besar dengan 119 gerai yang tersebar di seluruh Indonesia (Saputro, 2018). Ramayana telah menemani masyarakat Indonesia sejak tahun 1978 (Ramayana.co.id, n.d).
Munculnya kompetitor baru, kemudahan berbelanja secara daring, dan generasi baru, seperti generasi milenial yang memiliki perbedaan sikap dan perilaku dengan generasi sebelumnya, membuat Ramayana harus 
melakukan berbagai cara dalam promosi, termasuk penggunaan iklan untuk tetap bertahan dan menjaga eksistensinya.

Iklan menurut Advertising Association of the UK (ADASSOC.org.uk, n.d), adalah pesan yang dibayar oleh pengirim dan dimaksudkan untuk memberi tahu atau memengaruhi penerima pesan tersebut. Dalam bauran promosi (promotion mix), iklan merupakan salah satu bentuk alat selain sales promotion, personal selling, public relation, dan direct marketing (Kotler, 2000). Fungsi iklan dalam pemasaran tidak hanya menginformasikan dan mendorong kebutuhan maupun keinginan konsumen terhadap suatu produk, tetapi juga memiliki peranan penting dalam membangun brand image. Menurut Dobni dan Zinkhan (dikutip oleh Aaker \& Biel, 2009: 146), brand image sebagian besar merupakan fenomena subjektif dan perseptual yang terbentuk melalui interpretasi konsumen, secara rasional atau emosional. Sederhananya, brand image (brand image) adalah kumpulan asosiasi suatu brand yang terbentuk di benak konsumen. Adanya asosiasi brand ini tentunya dapat memberikan suatu nilai bagi perusahaan dan para pelanggan dengan membantu terciptanya diferensiasi yang dapat membedakan satu brand dengan lainnya.

Generasi milenial adalah orang-orang dengan rentang usia 19-34 tahun yang telah terpapar oleh kemajuan teknologi, seperti internet, sejak usia produktif (Moreno, dkk, 2017: 135). Generasi ini memiliki karakteristik cenderung aktif di media sosial dan suka mengonsumsi maupun membagikan konten yang menurut mereka menarik. Konten yang tidak menarik, termasuk iklan yang membosankan, akan cenderung dihindari dan dianggap mengganggu bagi mereka sebagai audiens. Dengan karakteristik tersebut dan populasi pengguna internet di Indonesia didominasi oleh generasi milenial (Yordan, 2018), Ramayana mencoba menggunakan pendekatan yang berbeda dalam membuat iklan agar dapat diterima semua kalangan, terutama generasi ini. Pendekatan tersebut adalah penggunaan daya tarikiklan yang menonjol dari iklan-iklan lain.

Pada tahun 2016 Ramayana memperkenalkan kampanye baru, yakni \#KerenHakSegalaBangsa, dengan menggunakan iklan televisi. Dalam iklan tersebut, Ramayana memberikan pesan kebebasan berekspresi dalam fashion yang menggunakan unsur humor. Ramayana ingin membangun citra sebagai department store yang mendukung pernyataan bahwa setiap orang berhak menjadi keren dengan menggunakan pakaian yang mereka sukai, namun harga terjangkau. Sejak saat itu, iklan Ramayana selalu menunjukkan kreativitas dalam iklannya sehingga sering kali menjadi populer atau viral di internet.

Pada tahun 2018, Ramayana kembali mengeluarkan iklan edisi Ramadan dengan tajuk "Ramayana Ramadan \#KerenLahirBatin Menyambut Lebaran" dan telah mendapatkan respon luar biasa dari audiens, terutama dari pengguna media sosial. Gideon (dikutip oleh Liputan6.com, 2017) menjelaskan, hal tersebut terbukti dari banyaknya penonton iklan yang berjumlah 700 ribu penonton meski baru sehari diunggah pada akun YouTube resmi Ramayana pada tanggal 16 Mei 2018. Selain itu, Pangerang (dikutip oleh Kompas.com, 2018), menyebutkan iklan "\#KerenLahirBatin" sempat menjadi "Trending" nomor 31 di YouTube. Hingga akhir 2018, iklan tersebut telah ditonton lebih dari dua belas juta kali dengan 9.806 komentar. Tidak hanya itu, banyaknya pengguna media sosial, seperti Twitter dan Instagram, juga ikut membagikan iklan tersebut baik dalam bentuk 
gambar, tautan, meme, bahkan parodi, seperti pada Gambar $1 \mathrm{Hal}$ ini menunjukkan bahwa Ramayana cukup mampu menarik perhatian generasi milenial sebagai audiens untuk menonton iklan melalui daya tarik dalam iklannya hingga menjadi populer.

\section{Gambar1. Respon Pengguna Media Sosial Twitter dan Instagram}
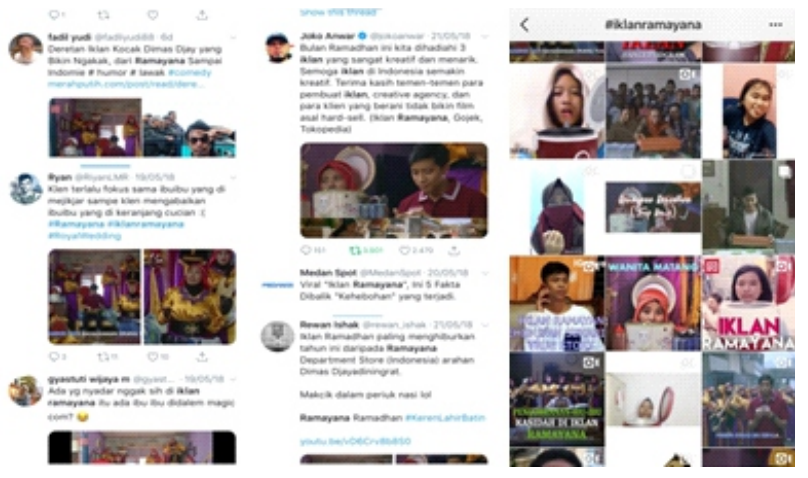

(sumber: https://mobile.twitter.com/hashtag

/iklanramayana?scr=hashtag_click dan

https://www.instagram.com/explore/tags/

iklanramayana/)

Menurut Meenaghan (1995: 1), periklanan memiliki peran penting untuk bermain dalam mengembangkan brand image, baik pada tingkat perusahaan, ritel atau produk. Periklanan dapat menginformasikan konsumen tentang kemampuan fungsional dari brand sekaligus menanamkan brand dengan nilai-nilai simbolis dan makna yang relevan dengan konsumen. Dengan kata lain, apa yang disampaikan melalui iklan dapat membentuk asosiasi-asosiasi tertentu pada sebuah brand, yang mana nantinya juga berpengaruh pada brand image itu sendiri. Brand image dalam hal ini dapat dilihat dari tiga komponen, yaitu strength of brand association, favorability of brand association, dan uniqueness of brand association (Keller, 1993: 3). Untuk menciptakan brand image yang kuat, konsumen harus diberikan informasi terstruktur, yang dapat tersimpan dalam bentuk memori dan kesadarannya sehingga mampu meningkatkan asosiasi brand (Isoraite, 2018: 1).

Pengiklan dapat menggunakan daya tarik iklan (advertising appeals) sebagai salah satu solusi agar konsumen memerhatikan iklan dan menangkap informasi yang ingin disampaikan. Kotler \& Keller (2012: 484) dan Sutisna (2001: 276), membagi daya tarik iklan menjadi daya tarik rasional dan emosional. Menurut Solomon (1992), daya tarik emosional menciptakan efek yang lebih mendasar pada sikap iklan berdasarkan jenis produk (dikutip oleh Akbari, 2015: 489). Weilbacher (1984: 197) melihat daya tarik rasional dari daya tarik harga yang menguntungkan (favorable price) dan berita (news appeals). Sedangkan daya tarik emosional dapat ditinjau dari jingle, unsur humor, kekeluargaan (Moriarty, 1991), dan kesenangan/kebahagiaan (fun) dalam iklan. Bentuk atau jenis daya tarik tersebut mendukung pembentukan asosiasi suatu brand.

Dalam penelitian yang telah dilakukan oleh Septa Adi Sasetyo (2012) tentang Pengaruh Daya Tarik Iklan terhadap Pembentukan Citra Merek Pepsodent, ditemukan bahwa persuasi dengan peripheralcues, seperti daya tarik pesan iklan yang menyentuh emosi audiens, penggunaan selebritas sebagai bintang iklan, format maupun gaya iklan Pepsodent yang ringan dan implisit, memengaruhi pembentukan brand image sebesar $22,8 \%$. Diikuti pengaruh isi pesan (central cues) sebesar $18,1 \%$, dan intensitas iklan sebesar $11,2 \%$ dari keseluruhan kemampuan iklan Pepsodent yang memiliki pengaruh sebesar 52,1\% terhadap pembentukan brand image Pepsodent di kalangan pelajar sekolah dasar. Seorang ayah dan anak sedang menyikat gigi yang ditampilkan maupun gaya pesan yang disampaikan dalam iklan Pepsodent berhasil memberikan asosiasi kegiatan 
sikat gigi yang menyenangkan, dan kejadian sehari-hari konsumen, seperti orang tua membujuk anaknya untuk menyikat gigi, yang mampu mengingatkan audiens pada Pepsodent.

Daya tarik iklan pada kasus iklan Ramayana "\#KerenLahirBatin" menggunakan beberapa unsur, seperti unsur humor yang menampilkan sekelompok wanita qasidah menyanyi dan seolaholah menjadi narator cerita seorang pria di tanah perantauannya. Diceritakan seorang pria yang takut jika ia tidak bisa pulang kampung dan tidak mampu membeli baju baru untuk keluarganya. Akhirnya, ia pun menemukan Ramayana Department Store sebagai solusi membeli baju baru untuk keluarga yang berada di kampung halaman. Selain itu, unsur humor tidak hanya ada pada cara kelompok kasidah menyanyi dan jalan cerita, tetapi juga hal-hal yang tidak masuk akal seperti kepala salah satu penyanyi yang muncul dari dalam penanak nasi.

\section{Gambar 2. Iklan Ramadan Ramayana 2018} "\#KerenLahirBatin"

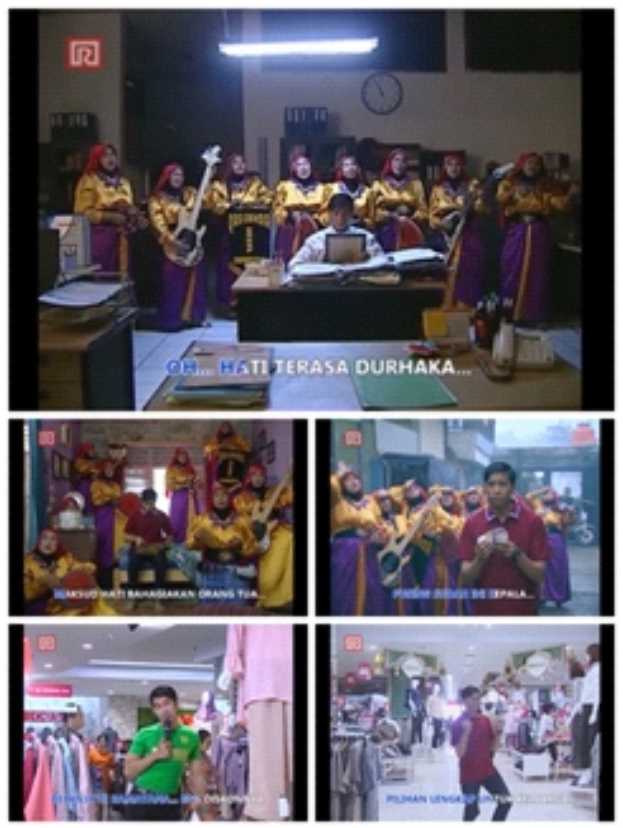

(sumber: Ramayana Department Store, tersedia di https://www.youtube.com/ watch?v=vD6Crv8b8S0)
Dari apa yang ditampilkan tersebut ternyata membuat iklan Ramayana versi Ramadan tahun ini menjadi populer dan mendapatkan reaksi yang cukup banyak dari audiens. Dengan kata lain, viralnya iklan ini yang disebarkan oleh pengguna internet tidak jauh dari pembahasan mengenai unsur-unsur yang berada dalam iklan. Oleh karena itu, daya tarik dalam Iklan Ramadan Ramayana menjadi menarik untuk dijadikan objek penelitian mengenai ada atau tidaknya pengaruh terhadap brand image Ramayana Department Store. Selain itu, mengenai penelitian tentang pengaruh daya tarik iklan tersebut terhadap brand image Ramayana Department Store di kalangan masyarakat milenial Indonesia, yang sekaligus merupakan pengguna aktif media sosial, masih belum banyak diungkapkan. Sebagian besar penelitian mengungkapkan pengaruh daya tarik iklan terhadap sikap, seperti yang dilakukan Sasmita (2015), Lin (2011), dan Akbari (2015), atau terhadap minat beli audiensnya, seperti dalam karya Jovanovic dan kawannya (2016), Prasetyono dan Soedarsono (2012), Lin (2011), Wijanarko (2009), Utami (2005), dan Zahra (2016).

Daya tarik iklan yang digunakan dalam iklan Ramayana dapat memberikan persepsi dan asosiasi tertentu terkait Ramayana yang nantinya disimpan dalam ingatan audiens, kemudian muncul ketika mereka menghadapi proses pengambilan keputusan pembelian. Untuk mengetahui pengaruh daya tarik iklan "\#KerenLahirBatin" terhadap brand image Ramayana, maka dilakukan penelitian berjudul "Pengaruh Daya Tarik Iklan terhadap Brand image Ramayana Department Store (Survei Iklan Ramadan Ramayana "\#KerenLahirBatin" di Kalangan Milenial Indonesia)".

Untuk mengetahui pengaruh daya tarik iklan terhadap brand image Ramayana Department Store, peneliti merumuskan 
beberapa indikator yang saling terhubung (Gambar 3). Penggunaan daya tarik iklan adalah salah satu bentuk upaya pengiklan menarik perhatian audiens agar tertarik melihat atau menonton iklan mereka. Iklan sendiri memiliki salah satu peran, yakni membentuk citra suatu produk, brand, atau perusahaan. Oleh karena itu, kajian ini melihat daya tarik iklan yang digunakan pengiklan dalam fungsinya membentuk brand image Ramayana.

\section{Gambar 3. Konsep Daya Tarik Iklan dalam Memengaruhi Brand image atau Brand Image}

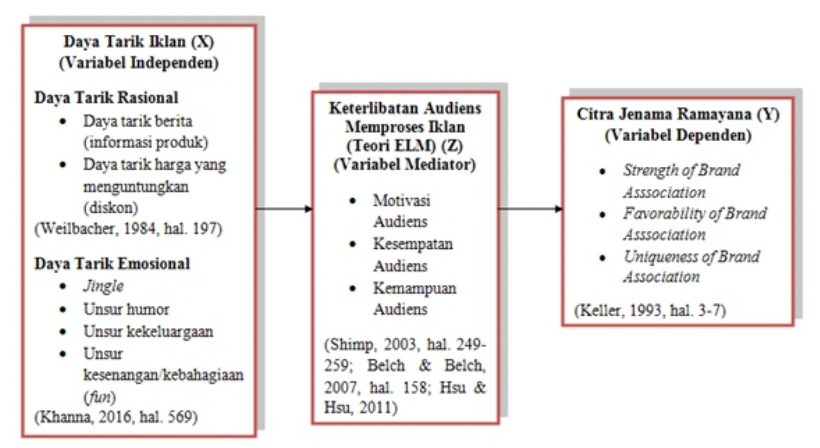

Daya tarik iklan dijadikan sebagai variabel independen atau variabel yang bersifat bebas, sedangkan brand image Ramayana dijadikan sebagai variabel dependen. Daya tarik iklan pada penelitian ini dapat dilihat dengan menggunakan konsep daya tarik iklan dari penelitian terdahulu, yakni adanya daya tarik rasional dan daya tarik emosional (Akbari, 2015; Khanna, 2016; Lin, 2011; Jovanovic, Vlastelica, \& Kostic, 2016). Seperti yang dipaparkan di atas, penggunaan daya tarik rasional menekankan pada kebutuhan praktis, fungsional, fitur, manfaat suatu produk dan/atau layanan atau alasan untuk menggunakan brand tertentu. Dengan penekanan tersebut, konsumen membuat keputusan pembelian berdasarkan logika dan penalaran individu (Khanna, 2016: 569). Lain halnya dengan daya tarik emosional, daya tarik ini berkaitan dengan kebutuhan sosial dan/atau psikologis konsumen untuk membeli produk atau layanan. Tidak sedikit motif konsumen dalam keputusan pembelian mereka bersifat emosional, yang mana perasaan mereka tentang jenama menjadi lebih penting dibandingkan pengetahuan tentang fitur atau atributnya. Daya tarik emosional menyentuh sisi kanan otak yang lebih kreatif sehingga tandatanda visual dalam iklan menjadi hal penting. Untuk meningkatkan efek persuasif iklan, pengiklan dapat menggunakan lebih dari satu jenis daya tarik baik rasional maupun emosional dalam iklannya (Khanna, 2016: 570).

Namun, untuk menangkap pesan yang disampaikan melalui iklan, audiens membutuhkan suatu proses yang dijelaskan dalam teori Elaboration Likelihood Model, yakni keterlibatan mereka memproses pesan iklan yang akan memengaruhi tingkat kecenderungan mereka mengelaborasi pesan dan perubahan sikap yang terjadi. Keterlibatan tersebut dapat dilihat dari MOA (motivasi, kesempatan, dan kemampuan) audiens memproses pesan iklan. Jika keterlibatan audiens (MOA) cenderung tinggi, maka kecenderungan elaborasi (EL) audiens terhadap pesan pun tinggi. Kekuatan MOA dan EL audiens menentukan jenis proses pesan yang nantinya memengaruhi sikapnya mengenai jenama dalam iklan, yakni jalur sentral (central route) dan jalur periferal (peripheral route).

Jalur sentral audiens akan aktif ketika MOA dan EL mereka tinggi sehingga lebih berfokus pada argumen pesan, bukan elemen-elemen periferal. Audiens yang termotivasi memperoleh informasi mengenai produk akan memengaruhi sikap mereka terhadap argumen pesan dalam iklan dengan memberikan respon kognitif dan emosional (Shimp, 2003: 240). Respon tersebut dapat bersifat positif (favorable) atau negatif 
(unfavorable) dan perubahan sikap yang terjadi dalam jalur ini bertahan lebih lama. Sedangkan jalur periferal akan aktif jika MOA dan EL audiens rendah. Oleh karena itu, mereka lebih bergantung pada elemen-elemen periferal, seperti musik, adegan, atau penampilan selebriti yang menarik. Sayangnya, perubahan sikap yang terjadi melalui jalur ini bersifat sementara.

Suatu brand dengan kekuatan posisi yang lebih tinggi dibandingkan dengan kompetitornya, dan adanya ketertarikan konsumen untuk memproses pesan iklan menjadi keunggulan suatu perusahaan. Hal tersebut dikarenakan, perusahaan sudah tidak perlu meningkatkan MOA audiensnya. Perusahaan hanya perlu menekankan bahwa jenama mereka lebih unggul dari jenama lain meskipun produk mereka sejenis. Namun, berbeda ketika jenama yang belum kuat memiliki kategori produk yang sama dengan jenama lainnya. Diperlukan upaya pengiklan untuk meningkatkan MOA yang bisa dilakukan dengan menggunakan daya tarik iklan, yakni gabungan dari argumen pesan dan elemenelemen periferal (Shimp, 2003: 240). Jika keterlibatan audiens (MOA) cenderung tinggi, maka kecenderungan elaborasi (EL) audiens terhadap pesan pun besar. Dengan begitu, audiens bisa lebih diarahkan untuk memproses pesan melalui jalur sentral, yang juga memungkinkan terjadinya perubahan sikap yang bertahan lama.

Untuk membuat audiens tetap menonton, membagikan, dan mengomentari iklan miliknya dan menembus "kebisingan" iklan kompetitor, Ramayana Department Store menggunakan daya tarik dalam iklannya "\#KerenLahirBatin" yang kemudian berhasil menjadi viral pada pertengahan tahun 2018 kemarin. Daya tarik dalam iklan tersebut, baik daya tarik rasional maupun emosional, akan dilihat dari kemampuannya meningkatkan MOA audiens dan pengaruhnya terhadap sikap, dalam hal ini citra yang dimiliki audiens terhadap jenama Ramayana Department Store setelah menonton iklan "\#KerenLahirBatin". Brand image dilihat dari tiga komponen menurut Keller (1993: 3-7), yaitu strength of brand association, favorability of brand association, dan uniqueness of brand association.

Berdasarkan latar belakang tersebut, maka rumusan masalah dalam penelitian ini berfokus pada pengaruh daya tarik Iklan Ramadan Ramayana versi "\#KerenLahirBatin" terhadap brand image Ramayana Department Store di kalangan masyarakat milenial Indonesia. Tujuan penelitian ini untuk dapat mendeskripsikan uji kuantitatif daya tarik iklan sebagai variabel $x$ dan brand image Ramayana Department Store sebagai variabely.

\section{Metode}

Penelitian ini menggunakan pendekatan kuantitatif dengan metode survei. Penggunaan metode survei diharapkan dapat membantu peneliti mengkaji sampel yang besar sesuai target penelitian dengan menggunakan kuesioner sebagai instrumennya. Oleh karena itu, pendekatan dan metode ini dipilih karena sejalan dengan tujuan peneliti yang ingin melihat pengaruh dari daya tarik dalam iklan terhadap brand image Ramayana Department Store di benak audiens tertentu, yakni generasi milenial Indonesia.

Dalam penelitian ini, peneliti menggunakan populasi masyarakat milenial di Indonesia berusia 19 hingga 34 tahun, dikarenakan generasi tersebut memiliki karakteristik sebagai pengguna yang tidak dapat jauh dari media sosial, konsumtif, dan suka membagikan konten-konten menghibur 
dan interaktif (Gould, 2014). Dengan karakteristik tersebut, maka besar kemungkinan untuk generasi milenial melihat maupun membagikan konten dengan daya tarik iklan yang unik, dalam hal ini iklan Ramayana.

Penelitian ini menggunakan generasi milenial di Indonesia yang berjumlah 100 orang sebagai sampel penelitian. Generasi milenial dipilih karena seperti yang telah disebutkan di atas, generasi ini memiliki kecenderungan tinggi untuk aktif di media sosial, konsumtif, dan suka membagikan konten-konten menghibur, dalam kasus ini iklan Ramayana. Sampel dicari dengan menggunakan non-probability sampling, yakni teknik sampling yang diterapkan atas pertimbangan tertentu, tergantung pada tujuan atau kepentingan peneliti. Rumus yang digunakan untuk mendapatkan jumlah sampel di atas adalah rumus Slovin.

$$
\begin{aligned}
& n=\frac{N}{1+N(e)^{2}} \\
& n=\frac{70.942 .352}{1+\left(70.942 .352 \times(0,1)^{2}\right)} \\
& n=100
\end{aligned}
$$

Keterangan:

$N \quad=$ Total populasi generasi milenial Indonesia

$n \quad=$ Ukuran sampel

$e \quad=$ Persentase tingkat kesalahan pengambilan sampel yang masih dapat ditolerir. Peneliti menggunakan confidence level sebesar $90 \%$ sehingga margin of error dalam penelitian ini adalah $10 \%$ atau 0,10 .

Metode survei daring adalah teknik pengumpulan data yang digunakan dalam penelitian ini. Metode ini mampu membantu peneliti untuk mengkaji sampel yang besar sesuai target penelitian dan dapat memberikan pertanyaan mengenai suatu topik lebih mudah dan tidak mengeluarkan banyak biaya karena disebarkan melalui internet.

Dalam memperoleh data, peneliti menyusun kuesioner secara sistematis dan standar pada survei tersebut agar mendapatkan data yang valid. Metode kuesioner atau angket adalah suatu cara pengumpulan data dengan menyebarkan daftar pertanyaan kepada responden, dengan harapan mereka akan memberikan respon atas daftar pertanyaan tersebut. Daftar pertanyaan yang disediakan peneliti bersifat tertutup, yaitu peneliti memberikan pertanyaan yang jawabannya sudah ditetapkan dengan menggunakan skala Likert. Dalam penelitian ini, peneliti menggunakan Google Forms. Proses penyusunan dan penyebaran kuesioner kepada target sampel di media sosial membutuhkan waktu kurang lebih sekitar dua bulan (akhir Desember 2018 hingga akhir Februari 2019). Adapun hipotesis penelitian adalah daya tarik iklan tidak memengaruhi brand image Ramayana Department Store sebagai HO dan daya tarik iklan memengaruhi brand image Ramayana Department Store sebagai $\mathrm{H} 1$.

\section{Temuan}

\section{Analisis Uji Korelasi (Pearson Correlation Test)}

Tabel di bawah adalah hasil uji analisis korelasi antara ketiga variabel yang digunakan dalam penelitian ini. Seperti yang telah disinggung sebelumnya, variabel $\mathrm{X}$ atau independen dalam penelitian ini adalah daya tarik iklan pada iklan "\#KerenLahirBatin", variabel Z atau mediator adalah keterlibatan audiens memproses iklan, sedangkan variabel $Y$ atau dependen adalah citra jenama pada Ramayana Department Store. 
Berdasarkan Tabel 1, hubungan antara variabel $X$ dan $Y$ dari nilai Korelasi Pearson menunjukkan angka 0,367 dan nilai signifikansi 0,000 . Dengan begitu, hubungan daya tarik iklan dan citra jenama Ramayana Department Store dapat dikatakan memiliki hubungan yang positif, lemah, dan signifikan.

Pada hubungan daya tarik iklan dengan keterlibatan audiens memproses iklan mendapatkan nilai Korelasi Pearson sebesar 0,771 dengan nilai signifikansi 0 . Ini artinya, hubungan keduanya bersifat positif, kuat, dan signifikan. Hubungan yang signifikan tersebut diperoleh dari nilai signifikansi 0,000 yang lebih kecil dari 0,1. Sedangkan untuk hubungan antara keterlibatan audiens memproses iklan dengan citra jenama Ramayana Department Store terlihat memiliki nilai Korelasi Pearson sebesar 0,385, yang artinya hubungan tersebut lemah. Kemudian, layaknya hubungan antar variabel sebelumnya, untuk nilai signifikansi kedua variabel tersebut juga menunjukkan nilai 0,000. Dari hasil ini, maka hubungan antara keterlibatan audiens memproses iklan dengan citra jenama Ramayana Department Store bersifat positif, lemah, dan signifikan.

Pada hubungan antara MOA dengan dimensi citra jenama Ramayana, hubungan tersebut secara keseluruhan bersifat lemah. MOA memiliki hubungan yang lemah dengan dimensi strength of brand association, kemudian memiliki hubungan yang cukup kuat dengan dimensi favorability of brand association. Sedangkan pada hubungan MOA dengan dimensi uniqueness of brand association, secara spesifik terdapat hubungan yang lemah dengan motivasi, tetapi tidak ada hubungan dengan kesempatan dan kemampuan audiens.

Dari hasil tersebut, maka dapat disimpulkan bahwa daya tarik iklan secara keseluruhan

Tabel 1

Hasil Uji Korelasi Pearson Secara Total

\begin{tabular}{|l|c|c|c|}
\hline & $\mathrm{X}$ & $\mathrm{Z}$ & $\mathrm{Y}$ \\
\hline $\mathrm{X} \quad$ Pearson Correlation & 1 & $.771^{* *}$ & $.367^{* *}$ \\
Sig. (2-tailed) & & .000 & .000 \\
N & 100 & 100 & 100 \\
\hline Pearson Correlation & $.771^{* *}$ & 1 & $.385^{* *}$ \\
Sig. (2-tailed) & .000 & & .000 \\
N & 100 & 100 & 100 \\
\hline Y Pearson Correlation & $.367^{* *}$ & $.385^{* *}$ & 1 \\
Sig. (2-tailed) & .000 & .000 & 100 \\
\hline N & 100 & 100 & \\
\hline
\end{tabular}

**. Correlation is significant at the 0,01 level (2-tailed).

Sumber: Data kuesioner, diolah 
berhubungan kuat dengan MOA. Secara spesifik, daya tarik emosional seperti jingle, unsur humor, unsur kekeluargaan, dan unsur menyenangkan, turut meningkatkan MOA audiens, atau memiliki pengaruh yang lebih kuat dibandingkan daya tarik rasional. Meskipun daya tarik emosional lebih mampu meningkatkan MOA audiens memproses iklan, tetapi dalam menyumbang kekuatan audiens mengasosiasikan Ramayana dan membentuk keunikan pada Ramayana yang dapat membedakan dengan jenama lain sangat lemah. Daya tarik emosional hanya mampu memberikan pengaruh pada tingkat kepercayaan audiens bahwa atribut dan manfaat jenama dapat memenuhi kebutuhan dan keinginan mereka. Dengan demikian, dapat dikatakan bahwa daya tarik rasional mengungguli hubungan dengan MOA audiens dan citra jenama Ramayana. Daya tarik rasional cukup kuat meningkatkan MOA audiens dan lebih mampu menunjang kekuatan audiens mengasosiasikan Ramayana, tingkat kepercayaan audiens, dan membentuk keunikan jenama Ramayana di benak audiens.

\section{Analisis Regresi}

Berbeda dengan analisis Korelasi Pearson yang hanya mengukur tingkat korelasi atau kekuatan hubungan antar variabel, analisis regresi merupakan teknik analisis yang akan dilakukan selanjutnya untuk mengetahui pengaruh suatu variabel terhadap variabel lain. Dalam penelitian ini, jenis analisis regresi yang digunakan adalah pengembangan dari regresi linier berganda, yaitu analisis jalur dengan program SPSS. Analisis jalur atau path analysis dibutuhkan untuk mengetahui pengaruh langsung maupun tidak langsung antara variabel independen dan variabel dependen yang juga dipengaruhi oleh variabel mediator. Dengan kata lain, daya tarik iklan dengan citra jenama
Ramayana Department Store di benak audiens juga akan dianalisis bagaimana pengaruh tidak langsung antara keduanya yang dipengaruhi oleh variabel mediator, yaitu keterlibatan audiens (MOA audiens).

Analisis jalur dilakukan dengan mencari terlebih dahulu signifikansi hubungan dan nilah pengaruh dari variabel daya tarik iklan (X) terhadap variabel keterlibatan audiens memproses iklan sebagai variabel mediator (Z). Pengujian ini merupakan uji regresi pertama yang hasilnya ditampilkan dalam Tabel 2.

Daya tarik iklan dalam uji regresi pertama ini dibagi sesuai jenisnya, yaitu daya tarik rasional dan daya tarik emosional. Hasil dari pengujian menunjukkan angka konstan dari Unstandardized Coefficients adalah $-2,074$, yang berarti jika tidak ada kedua daya tarik iklan tersebut, maka nilai konsistensi MOA audiens adalah sebesar -2,074. Selanjutnya, angka koefisien regresi yang diperoleh daya tarik rasional sebesar 0,775 mengartikan bahwa setiap penambahan $1 \%$ pengaruh daya tarik rasional, maka MOA audiens akan meningkat sebesar 0,775 . Untuk daya tarik emosional, angka koefisien regresi yang diperoleh sebesar 1,517. Hal tersebut mengindikasikan, setiap penambahan $1 \%$ pengaruh daya tarik emosional, MOA audiens pun bertambah 1,517. Nilai yang diperoleh kedua daya tarik iklan positif sehingga dapat dikatakan berpengaruh positif terhadap MOA audiens.

Untuk memastikan koefisien regresi di atas signifikan atau tidak, perbandingan nilai signifikansi dengan probabilitas 0,1 dilakukan. Nilai signifikansi keduanya mendapatkan 0,000 yang berarti lebih kecil dari 0,1. Ini artinya koefisien regresi signifikan atau variabel kedua daya tarik iklan benar-benar berpengaruh terhadap MOA audiens, dan memiliki hubungan yang signifikan. Selain itu, pengujian ini juga dapat 
mengetahui besaran nilai pengaruh variabel independen terhadap variabel mediator melalui Standardized Coefficients. Daya tarik rasional memiliki nilai pengaruh sebesar 0,352 , sedangkan daya tarik emosional menunjukkan nilai pengaruh sebesar 0,535. Melihat kedua hasil angka, baik dari Unstandardized Coefficients maupun Standardized Coefficients, maka nilai pengaruh yang ditimbulkan daya tarik emosional terhadap MOA audiens lebih besar jika dibandingkan dengan nilai pengaruh dari daya tarik rasional. Uji regresi kedua kemudian dilakukan untuk mengetahui nilai pengaruh dan signifikansi hubungan dari variabel daya tarik iklan dan variabel keterlibatan audiens memproses iklan terhadap citra jenama Ramayana Department Store.

Hasil dari uji regresi kedua pada Tabel memperlihatkan angka konstan kedua daya tarik iklan dan keterlibatan audiens dari Unstandardized Coefficients adalah 37,968, yang berarti jika tidak ada kedua daya tarik iklan tersebut, maka nilai konsistensi citra jenama Ramayana Department Store adalah sebesar 37,968. Kemudian, angka koefisien regresi yang diperoleh daya tarik rasional sebesar 0,467 mengartikan bahwa setiap penambahan $1 \%$ pengaruh daya tarik rasional, maka citra jenama Ramayana audiens akan meningkat sebesar 0,467 . Untuk daya tarik emosional, angka koefisien regresi yang diperoleh sebesar -0,245. $\mathrm{Hal}$ tersebut mengindikasikan, setiap penambahan $1 \%$ pengaruh daya tarik emosional, citra jenama Ramayana berkurang sebesar 0,245. Dengan kata lain, nilai negatif ini juga berarti bahwa ketika daya tarik emosional semakin

Tabel 2

Hasil Uji Regresi Variabel Independen terhadap Variabel Mediator

\begin{tabular}{|c|c|c|c|c|c|c|c|}
\hline & & \multicolumn{6}{|c|}{ Model Summary } \\
\hline & & Model & $R$ & $R$ Square & $\begin{array}{c}\text { Adjusted } R \\
\text { Square }\end{array}$ & $\begin{array}{l}\text { Std. Error of } \\
\text { the Estimate }\end{array}$ & \\
\hline & & 1 & $.784^{\mathrm{a}}$ & .615 & .607 & 6.18457 & \\
\hline \multicolumn{8}{|c|}{ a. Predictors: (Constant), DTE, DTR } \\
\hline & del & & $B$ & Std. Error & Beta & $t$ & Sig. \\
\hline \multirow[t]{3}{*}{1} & (Constant) & & 2.074 & 4.677 & & -.443 & .659 \\
\hline & DTR & & .775 & .165 & .352 & 4.687 & .000 \\
\hline & DTE & & 1.517 & .213 & .535 & 7.122 & .000 \\
\hline
\end{tabular}

a. Dependent Variable: Z (MOA Audiens) 
bertambah, citra jenama Ramayana Department Store di benak audiens justru mengalami penurunan. Sedangkan untuk variabel keterlibatan audiens dalam memproses iklan memiliki angka koefisien regresi sebesar 0,273, yang mana setiap adanya penambahan $1 \%$ keterlibatan audiens, citra jenama Ramayana Department Store di benak audiens meningkat sebesar 0,273.

Untuk memastikan koefisien regresi di atas signifikan atau tidak, perbandingan nilai signifikansi dengan probabilitas 0,1 dilakukan. Nilai signifikansi daya tarik rasional mendapatkan 0,056 yang berarti lebih kecil dari 0,1 sehingga koefisien regresi daya tarik ini dapat dikatakan signifikan atau memiliki pengaruh terhadap citra jenama. Lain hal pada daya tarik emosional, nilai signifikansi yang diperoleh adalah sebesar 0,481 yang berarti lebih besar dari 0,1. Ini artinya, koefisien regresi tidak signifikan, atau daya tarik emosional tidak ada pengaruh terhadap citra jenama Ramayana Department Store di benak audiens. Sedangkan nilai signifikansi keterlibatan audiens memperoleh 0,044 yang lebih kecil dari 0,1 . Dengan begitu, koefisien regresi keterlibatan audiens signifikan, atau keterlibatan audiens memproses iklan memang berpengaruh terhadap citra jenama Ramayana Department Store di benak audiens.

Jika melihat hasil nilai pengaruh variabel

Tabel 3

Hasil Uji Regresi Variabel Independen dan Variabel Mediator terhadap Variabel Dependen

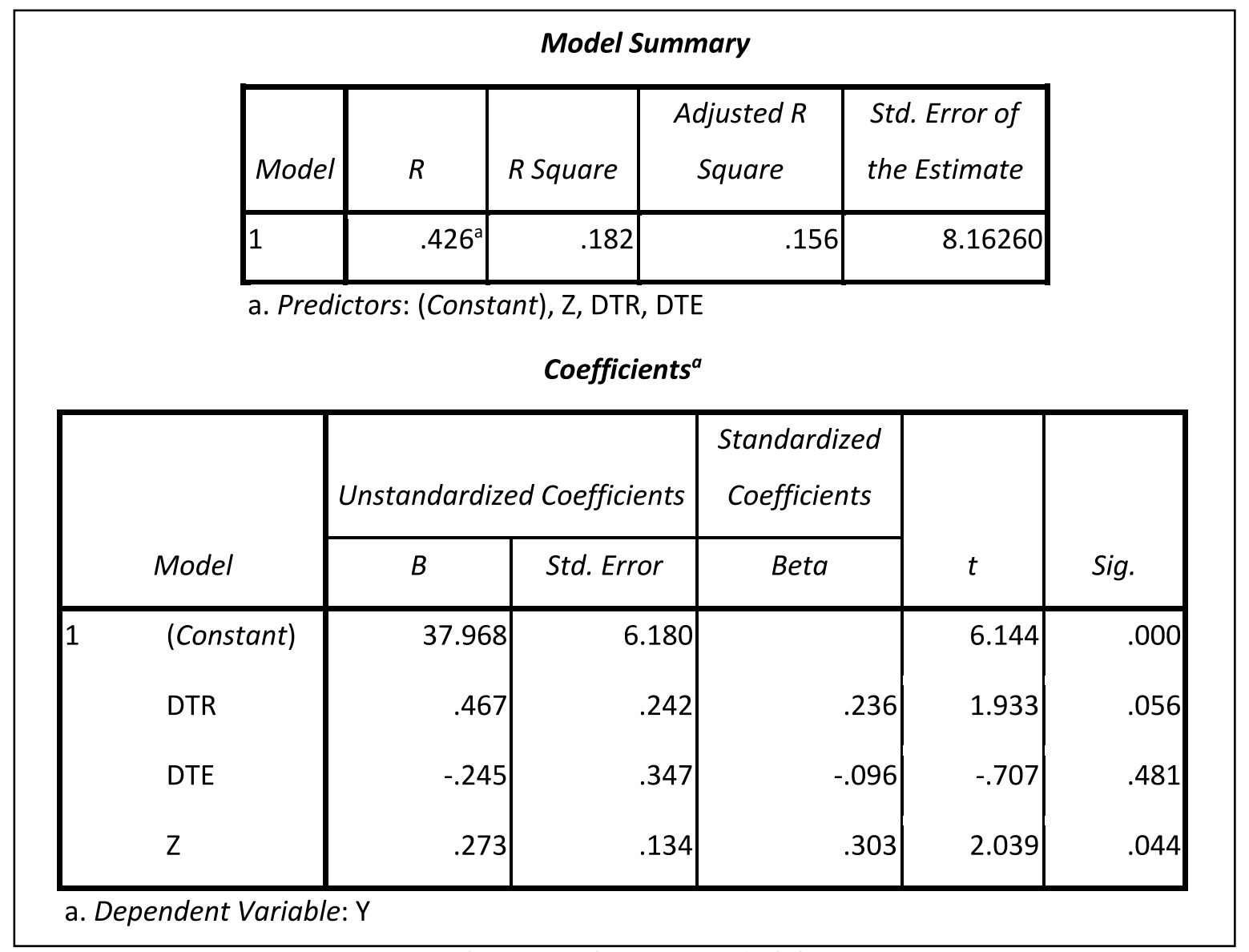

Sumber: Data kuesioner, diolah 
independen dan variabel mediator terhadap variabel dependen melalui Standardized Coefficients, daya tarik rasional secara langsung memiliki nilai pengaruh sebesar 0,236 , sedangkan daya tarik emosional tidak memiliki pengaruh. Untuk keterlibatan audiens, diperoleh nilai pengaruh terhadap citra jenama Ramayana Department Store sebesar 0,303.

Dari hasil uji regresi pertama dan kedua, peneliti memetakan nilai pengaruh yang dilihat dari Standardized Coefficients variabel daya tarik iklan dan variabel keterlibatan audiens terhadap variabel citra jenama Ramayana Department Store ke dalam bagan. Hal ini bertujuan untuk memudahkan peneliti menganalisis terkait pengaruh antar ketiga variabel tersebut.

Sesuai dengan cara analisis jalur, bagan di atas memperlihatkan bahwa terdapat pengaruh langsung maupun tidak langsung daya tarik iklan terhadap citra jenama Ramayana Department Store. Pengaruh tidak langsung ini berarti bahwa daya tarik iklan harus melalui variabel mediator, yaitu keterlibatan audiens dalam memproses iklan. Karena nilai pengaruh langsung sudah diketahui, maka nilai pengaruh tidak langsung dapat dicari dengan mengalikan nilai pengaruh variabel independen terhadap variabel mediator dengan nilai pengaruh variabel mediator terhadap variabel dependen.

Nilai pengaruh tidak langsung daya tarik rasional melalui keterlibatan audiens atau MOA audiens terhadap citra jenama Ramayana Department Store diperoleh dari hasil perkalian $0,352 \times 0,303=0,106$. Sedangkan untuk pengaruh tidak langsung daya tarik emosional terhadap citra jenama Ramayana Department Store didapatkan dari hasil perkalian 0,535 $\times 0,303=$ 0,162 . Melalui perhitungan ini, diperoleh hasil yang menarik bahwa pengaruh langsung daya tarik rasional terhadap citra jenama Ramayana Department Store memiliki nilai yang lebih besar dibandingkan dengan pengaruh tidak langsung yang diintervensi oleh variabel MOA audiens $(0,236>0,106)$. Selain itu, daya tarik emosional ternyata tidak berkontribusi secara langsung terhadap pembentukan citra jenama Ramayana Department Store karena nilai pengaruh yang diperoleh sebesar -0,96 dengan nilai signifikansi lebih besar dari 0,1. Namun, daya tarik emosional memiliki pengaruh tidak langsung terhadap citra jenama yang diintervensi oleh variabel MOA audiens dengan nilai pengaruh sebesar 0,162.

Bagan 2 menunjukkan bahwa daya tarik iklan secara keseluruhan memiliki nilai pengaruh dari Standardized Coefficient sebesar 0,771 terhadap keterlibatan audiens memproses iklan,

\section{Bagan 1}

Peta Hasil Uji Regresi Variabel Independen, Variabel Mediator, dan Variabel Dependen

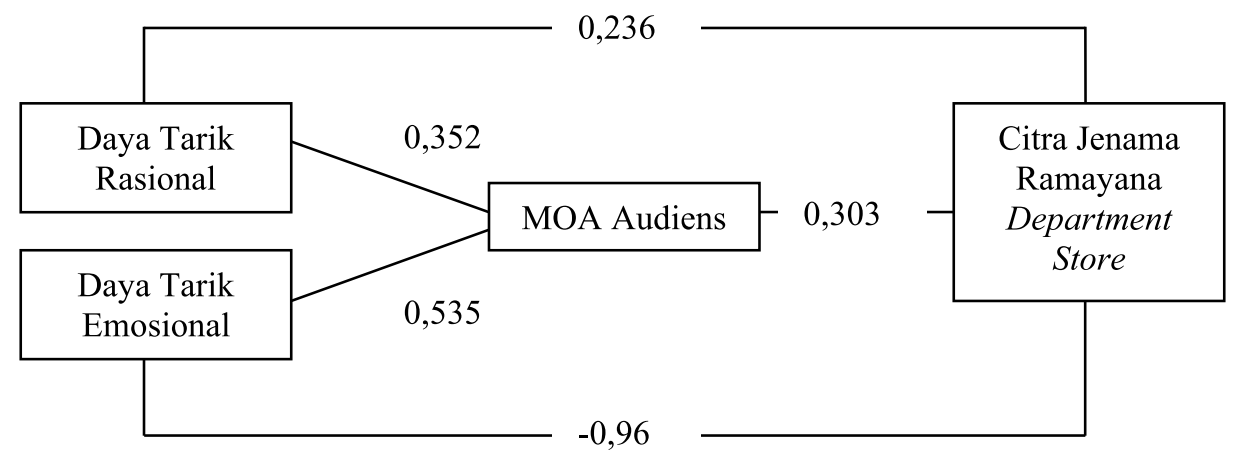

Sumber: Data kuesioner, diolah 
dengan nilai signifikansi 0,000 yang lebih besar dari 0,1. Hal tersebut dapat dikatakan bahwa daya tarik iklan secara keseluruhan memang memiliki pengaruh terhadap perubahan MOA audiens. Sedangkan nilai pengaruh variabel keterlibatan audiens terhadap citra jenama sendiri, memperoleh nilai pengaruh sebesar 0,251 dengan nilai signifikansi $0,089<0,1$, yang juga berarti variabel ini benar-benar memiliki pengaruh terhadap variabel Y. Untuk mencari nilai pengaruh tidak langsung daya tarik iklan melalui keterlibatan audiens terhadap citra jenama Ramayana Department Store, dilakukan perkalian dari 0,771 x 0,251 =0,193. Jika melihat Bagan 2, nilai pengaruh langsung daya tarik iklan terhadap citra jenama adalah sebesar 0,173. Kedua hasil dari nilai pengaruh langsung dan tidak langsung menunjukkan bahwa nilai pengaruh tidak langsung daya tarik iklan secara keseluruhan lebih besar daripada nilai pengaruh langsung daya tarik iklan secara keseluruhan terhadap citra jenama Ramayana Department Store $(0,193>0,173)$.

Dari pengujian regresi di atas dapat disimpulkan bahwa jika daya tarik iklan diuji berdasarkan jenisnya, yaitu daya tarik rasional dan daya tarik emosional, maka hasil nilai pengaruhnya terhadap citra jenama Ramayana Department Store berbeda dengan hasil nilai pengaruh ketika daya tarik iklan diuji sebagai suatu kesatuan. Jika daya tarik iklan diuji secara terpisah, hasil nilai pengaruh langsung lebih besar dibandingkan nilai pengaruh tidak langsung $(0,236>0,106 ; 0,162)$. Namun pada kasus ini, hanya daya tarik rasional yang memiliki pengaruh langsung. Sedangkan ketika nilai pengaruh daya tarik iklan secara keseluruhan atau gabungan dari daya tarik rasional dan daya tarik emosional dicari, nilai pengaruh tidak langsung daya tarik iklan lebih besar dari nilai pengaruh langsung $(0,193>0,173)$. Pada pengujian daya tarik iklan yang

Tabel 4

Hasil Uji Regresi Variabel Independen Secara Keseluruhan dan Variabel Mediator terhadap Variabel Dependen

Model Summary

\begin{tabular}{|c|c|c|c|c|}
\hline Model & $R$ & $R$ Square & Adjusted $R$ Square & Std. Error of the Estimate \\
\hline 1 & $.401^{\mathrm{a}}$ & .160 & .143 & 8.22527 \\
\hline
\end{tabular}

a. Predictors: (Constant), $\mathrm{Z}, \mathrm{X}$

Sumber: Data kuesioner, diolah

Bagan 2

Peta Hasil Uji Regresi Variabel Independen Secara Keseluruhan, Variabel Mediator, dan Variabel Dependen

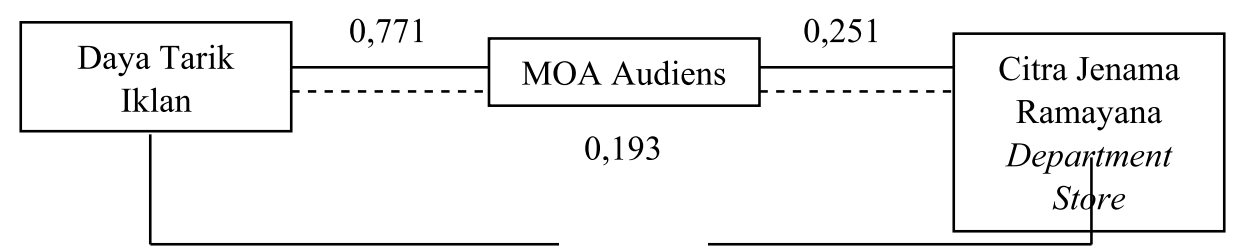

0,173

Sumber: Data kuesioner, diolah 
terpisah, meskipun daya tarik emosional tidak memiliki pengaruh langsung terhadap citra jenama, tetapi daya tarik ini memiliki pengaruh yang lebih besar terhadap peningkatan MOA audiens dibandingkan daya tarik rasional. Daya tarik emosional juga memperoleh nilai pengaruh tidak langsung terhadap citra jenama yang lebih besar dibandingkan daya tarik rasional. Hal ini bisa jadi dikarenakan unsur-unsur pada daya tarik emosional lebih mampu membangkitkan motivasi, kesempatan, dan kemampuan responden memproses iklan "\#KerenLahirBatin" mengingat pada hasil analisis mean, responden cenderung lebih merasakan keberadaan dan pengaruh dari unsur-unsur daya tarik emosional. Peningkatan MOA audiens ini kemudian menyumbang pengaruh terhadap citra jenama Ramayana Department Store.

Selain itu, apabila melihat nilai $\mathrm{R}$ Square dalam Tabel 4.13, maka diperoleh angka 0,160, yang berarti pengaruh daya tarik iklan yang mencakup daya tarik rasional dan daya tarik emosional sebagai variabel independen, keterlibatan audiens memproses iklan sebagai variabel mediator, hanya berkontribusi sebesar $16 \%$ terhadap citra jenama Ramayana Department Store sebagai variabel dependen. Dari angka tersebut, maka $84 \%$ citra jenama Ramayana Department Store dibentuk oleh faktor-faktor lain di luar kemampuan daya tarik iklan dalam iklan "\#KerenLahirBatin”.

\section{Pembahasan}

Temuan yang diperoleh dalam penelitian ini menjawab rumusan masalah bahwa daya tarik iklan memang memiliki pengaruh terhadap citra jenama Ramayana Department Store. $\mathrm{H} 1$ yang menyatakan bahwa daya tarik iklan memengaruhi citra jenama Ramayana Department Store diterima, sedangkan $\mathrm{HO}$ yang menyatakan bahwa daya tarik iklan tidak memengaruhi citra jenama Ramayana Department Store ditolak. Daya tarik iklan secara signifikan dan kuat memengaruhi keterlibatan responden. Meskipun demikian, pengaruh keterlibatan responden terhadap citra jenama bersifat signifikan, tetapi lemah. Sedangkan untuk pengaruh langsung dari daya tarik iklan terhadap citra jenama, pengaruh tersebut secara signifikan memengaruhi citra jenama, tetapi juga bersifat lemah. Perbandingan besarnya pengaruh langsung dan tidak langsung daya tarik iklan terhadap citra jenama juga dilakukan dengan menggunakan analisis jalur. Hasilnya, nilai pengaruh tidak langsung daya tarik iklan yang dijembatani oleh keterlibatan responden terhadap citra jenama lebih besar dibandingkan nilai pengaruh langsung dari daya

Tabel 5

Hasil Uji Regresi Variabel Independen terhadap Variabel Dependen

Model Summary

\begin{tabular}{|c|c|c|c|c|}
\hline Model & $R$ & $R$ Square & Adjusted R Square & Std. Error of the Estimate \\
\hline 1 & $.367^{\mathrm{a}}$ & .135 & .126 & 8.30706 \\
\hline
\end{tabular}

a. Predictors: (Constant), $X$

Sumber: Data kuesioner, diolah 
tarik iklan yang tidak melalui proses keterlibatan responden.

Daya tarik iklan diukur dari dua jenis atau kategori, yaitu daya tarik rasional dan daya tarik emosional yang telah disesuaikan dengan daya tarik iklan dalam iklan "\#KerenLahirBatin". Daya tarik rasional sendiri terdiri dari daya tarik berita atau informasi produk, dan daya tarik diskon. Sedangkan daya tarik emosional terdiri dari penggunaan jingle, unsur humor, unsur kekeluargaan, dan unsur menyenangkan (fun). Keterlibatan audiens memproses iklan merupakan sebuah konsep yang diambil dari teori ELM, yang mana dalam teori tersebut, keterlibatan dapat dilihat dari motivasi, kesempatan, dan kemampuan audiens (MOA audiens) memproses pesan iklan. Semakin tinggi MOA audiens, maka kecenderungan elaborasi audiens pun semakin tinggi sehingga audiens bisa lebih diarahkan untuk memproses pesan melalui jalur sentral, yang mana perubahan sikap mengenai jenama dalam iklan yang terjadi bertahan lebih lama dibandingkan melalui jalur periferal. Sedangkan citra jenama Ramayana Department Store dikaji melalui tiga dimensi, yaitu strength of brand association, favorability of brand association, dan uniqueness of brand association.

Dari ketiga variabel di atas, terbentuk 42 butir pernyataan yang digunakan dalam kuesioner. Kuesioner ini kemudian disebarkan secara daring kepada responden generasi milenial berusia 19-34 tahun yang aktif menggunakan media sosial, dan pernah menonton iklan Ramayana "\#KerenLahirBatin". Hasil penyebaran tersebut diperoleh jawaban dari 100 responden yang selanjutnya diolah menggunakan program SPSS.

Meskipun target responden mencakup mereka yang berumur 19 hingga 34 tahun, tetapi dalam penelitian ini hanya memperoleh responden dengan usia 19-25 tahun. Dari rentang usia tersebut, responden penelitian ini didominasi mereka yang berusia 21 tahun. Sejalan dengan dominasi usia, profesi terbanyak dalam penelitian ini merupakan pelajar/mahasiswa dengan pengeluaran yang masih bergantung pada uang saku dari orang tua sekitar Rp 500.000-1.500.000 perbulan.

Pelajar atau mahasiswa cenderung memiliki waktu luang yang lebih banyak dibandingkan mereka yang sudah bekerja. Untuk kebutuhan akademik maupun hiburan, pelajar/mahasiswa biasanya bergantung pada internet sehingga waktu yang dihabiskan untuk mengakses internet pun tidak sedikit. Hal tersebut terbukti dari hasil frekuensi responden mengakses internet dalam penelitian ini didominasi jawaban lebih dari enam (>6) jam per hari. Ini artinya, generasi milenial memang tidak bisa jauh dari internet sehingga kecenderungan responden untuk memperoleh informasi sebanyak mungkin sekaligus terpapar iklan di internet sangatlah besar.

Daya tarik iklan secara signifikan dan kuat memengaruhi keterlibatan responden. Hal tersebut terbukti dari daya tarik iklan, baik daya tarik rasional dan daya tarik emosional yang mampu meningkatkan motivasi, kesempatan, dan kemampuan responden memproses iklan. Namun secara spesifik, daya tarik emosional merupakan daya tarik iklan yang mendominasi dalam memengaruhi MOA karena daya tarik ini memiliki nilai pengaruh yang lebih kuat dalam meningkatkan MOA dibandingkan daya tarik rasional. Dominasi pengaruh daya tarik emosional juga dilatarbelakangi oleh iklan "\#KerenLahirBatin" yang tidak banyak memberikan informasi tentang produk, argumentasi pesan lemah, dan lebih berfokus pada iklan yang menghibur. Maka, responden pun lebih banyak menerima elemen-elemen dari daya 
tarik emosional dibandingkan elemen dari daya tarik rasional.

Adapun elemen yang mengungguli kemampuan dalam meningkatkan MOA responden dari daya tarik emosional adalah penggunaan unsur humor, menyenangkan, jingle, ditambah populernya iklan. Namun, bagi sebagian responden yang masih sering mencermati iklan, informasi produk yang mudah diingat dan penawaran diskon dari daya tarik rasional juga mampu memotivasi mereka untuk menyaksikan iklan.

Hasil responden menyetujui elemen yang mampu meningkatkan MOA tersebut sejalan dengan penelitian yang dilakukan Khanna (2016) seperti yang disinggung dalam bab satu dan dua, bahwa penggunaan daya tarik emosional, yaitu unsur kesenangan/kebahagiaan, jingle, slogan, maupun humor merupakan daya tarik yang biasanya hadir di setiap iklan dan membentuk dasar daya tarik dalam iklan. Khanna (2016: 571) juga menjelaskan bahwa untuk mengatasi kebisingan iklan dan supaya menonjol di antara iklan lainnya, perusahaan kini semakin menggunakan humor dalam iklan mereka sebagai upaya membuat audiens menonton, tertawa, menikmati, dan yang paling penting membantu audiens mengingat jenama. Iklan yang lucu mampu memberikan ingatan yang lebih baik dan mudah diterima karena dapat meningkatkan kebahagiaan dan suasana hati konsumen. Jika melihat kembali iklan tersebut, penggunaan unsur humor semakin mudah diingat karena cara penyampaian dalam iklan yang berbeda. Jalan cerita, adanya sekelompok wanita kasidah sedang bernyanyi, bahkan hal yang tidak masuk akal, seperti salah satu penyanyi yang muncul dari dalam penanak nasi, merupakan hal baru yang belum ditemui pada iklan lainnya. Dengan begitu, penggunaan unsur humor ini lebih mampu diterima dan ditangkap responden sehingga proses penerimaan maupun pemahaman maksud iklan pun lebih mudah dibandingkan unsur lainnya.

Jingle secara umum digunakan agar audiens dapat dengan mudah mengingat iklan maupun jenama yang diiklankan. Jingle juga berpotensi menarik minat, dan perhatian audiens apalagi jika dimanfaatkan ketika konsumen sudah bosan dengan bentuk iklan yang cenderung sama (Crescendo, 2015). Dengan kata lain, penggunaan jingle yang tidak biasa, mudah diingat, ditambah populer di berbagai media sosial dapat menjadi daya tarik sendiri bagi audiens. Kemenarikan jingle turut memicu audiens untuk mencari tahu asal-usul jingle yang kemudian membuat mereka menonton iklan dan mengenal jenama yang memproduksi iklan tersebut. Pada iklan "\#KerenLahirBatin", jingle yang diawali dengan "kerja lembur bagai kuda" ini seringkali dijadikan bahan konten di berbagai media sosial. Generasi milenial memiliki kecenderungan untuk membagikan hal-hal yang menurut mereka menarik. Kata-kata tersebut dianggap mereka menarik sehingga berhasil menjadi viral atau populer. Audiens pun menjadi hafal maupun dapat mengasosiasikan kata-kata tersebut adalah jingle milik Ramayana Department Store.

Popularitas tersebut berkaitan dengan hasil responden menyetujui bahwa kepopuleran iklan membantu meningkatkan kesempatan mereka dalam memproses iklan. Ini artinya, kepopuleran iklan, terutama di media sosial, memang memiliki kemampuan untuk membangun kesadaran jenama atau menciptakan potensi pertumbuhan eksponensial dalam paparan dan pengaruh pesan dengan cepat sesuai pernyataan dalam penelitian Karpasitis (2017: 26). Dengan begitu, adanya iklan dan informasi tentang jenama yang tersebar di mana-mana memudahkan milenial sebagai 
responden untuk terpapar iklan sekaligus memahami iklan secepat mungkin.

Temuan bahwa daya tarik iklan, terutama dari daya tarik emosional mampu memengaruhi MOA responden tersebut membuktikan pernyataan bahwa daya tarik iklan secara signifikan dan kuat memengaruhi keterlibatan responden. Hal ini juga sejalan dengan hasil penelitian Sasmita yang dijelaskan dalam bab dua dan mendukung pernyataan Kotler \& Amstrong (2012: 2) bahwa daya tarik iklan memang memiliki kemampuan membangkitkan minat, motivasi, dan alasan konsumen mempertimbangkan produk yang diiklankan.

Dalam teori ELM, daya tarik emosional adalah elemen periferal yang diandalkan audiens ketika tingkat MOA rendah dan mengakibatkan kecenderungan untuk mengelaborasi pesan juga rendah (Shimp, 2003: 247). Kekuatan MOA dan EL menentukan jenis pemrosesan pesan antara jalur sentral atau jalur periferal. Jika melihat peta konsep teori ELM milik Griffin pada Gambar 1.4, maka hasil daya tarik emosional yang mendominasi ini menandakan bahwa responden memiliki keterlibatan memproses komunikasi persuasif yang rendah. Menurut Petty $\&$ Cacioppo (dikutip oleh Hyunjoo \& Jasper, 2006: 17), pada tingkat keterlibatan rendah, audiens biasanya tidak berusaha untuk memproses argumen pesan, tetapi mereka membentuk sikap terhadap produk melalui pemrosesan periferal. Tanpa mencermati informasi yang relevan tentang produk, mereka mendasarkan sikap produk pada elemen periferal. Dengan kata lain, responden pun cenderung mengandalkan elemen seperti penggunaan musik, humor, dan visual, yang kemudian mengarahkan pemrosesan pesan pada jalur periferal.

Seperti yang telah dipaparkan dalam bab satu dan dua, ketika jalur pemrosesan pesan berada di jalur periferal, maka perubahan sikap yang muncul terlepas dari sifatnya yang positif atau negatif, akan hanya bertahan sementara dan lemah karena tidak melalui proses kognitif seperti pada jalur sentral (Sutisna, 200: 127). Karena pengaruh yang timbul melalui jalur periferal cenderung lemah, maka pengaruh yang diberikan dari keterlibatan responden terhadap citra jenama dalam penelitian ini pun lemah.

Selain daya tarik emosional mendapatkan hasil bahwa daya tarik ini memiliki pengaruh terhadap MOA responden yang lebih besar dibandingkan daya tarik rasional, daya tarik emosional juga memiliki hasil pengaruh tidak langsung yang lebih besar terhadap pembentukan citra jenama dibandingkan pengaruh tidak langsung daya tarik rasional terhadap pembentukan citra jenama. Meskipun demikian, daya tarik emosional ini hanya kuat dalam memengaruhi tingkat kepercayaan responden bahwa atribut dan manfaat jenama Ramayana dapat memenuhi kebutuhan dan keinginan mereka. Daya tarik emosional tidak dapat menunjang kekuatan responden mengasosiasikan Ramayana dan membentuk keunikan jenama Ramayana di benak responden. Sedangkan daya tarik rasional memiliki kemampuan memengaruhi MOA responden, tetapi juga sekaligus memengaruhi ketiga dimensi citra jenama tersebut, terutama dari daya tarik diskon. Namun, karena iklan ini didominasi oleh daya tarik emosional yang pada umumnya mengarahkan pemrosesan pesan pada jalur periferal, maka pengaruh yang timbul pun hanya bertahan sementara dan bersifat lemah. Hal ini konsisten dengan pernyataan bahwa keterlibatan audiens memiliki pengaruh yang berbanding lurus terhadap pembentukan citra jenama, tapi dengan kekuatan yang lemah.

Meskipun kekuatannya lemah, hasil 
penelitian terkait dengan variabel yang dipengaruhi secara keseluruhan menunjukkan bahwa citra yang ada di benak responden mengenai jenama Ramayana Department Store pun bersifat positif. Responden paling setuju dengan anggapan bahwa Ramayana merupakan jenama toko dengan nilai-nilai yang sudah sesuai untuk target konsumennya. Ramayana dianggap selalu menyediakan produk-produk dengan harga yang wajar, tetapi tetap berkualitas dan bergaya masa kini kepada target konsumennya, yaitu masyarakat Indonesia menengah ke bawah. Ramayana juga diyakini responden sebagai jenama dengan cara promosi yang dapat menimbulkan citra positif. Hal tersebut terlihat dari iklan-iklan kreatifnya yang disambut baik oleh pengguna internet. Terakhir, dengan keunggulan Ramayana yang mudah dicari di beberapa mal di seluruh Indonesia maupun melalui e-commerce, harga terjangkau, dan selalu mencoba mengikuti tren membuat responden cenderung yakin bahwa Ramayana masih mampu bersaing dengan jenama lainnya.

Hasil diatas cukup membuktikan bahwa iklan memiliki fungsi yang berarti dalam membangun citra suatu jenama. Identitas yang ingin dibangun Ramayana melalui iklan dalam penelitian ini sebagian besar berhasil ditangkap menjadi sekumpulan asosiasi yang kemudian terbentuk menjadi suatu persepsi bersifat positif di benak audiens. Citra yang dimiliki responden tersebut tentunya tidak hanya terbentuk dari atribut fungsional jenama dalam iklan, tetapi juga melibatkan nilai-nilai simbolis jenama yang tersirat dalam iklan. Hal ini pun turut mendukung pernyataan Meenaghan (1995: 7) dalam bab dua yang menyatakan bahwa citra jenama yang dibentuk oleh konsumen merupakan gabungan dari aspek fungsional dan emosional yang diserap secara bersamaan.
Daya tarik iklan dan keterlibatan responden memproses pesan secara keseluruhan memiliki pengaruh terhadap pembentukan citra jenama Ramayana Department Store, tetapi hanya sebesar $16 \%$. Kecilnya persentase tersebut menunjukkan bahwa $84 \%$ citra jenama Ramayana Department Store dibentuk oleh faktor-faktor lain di luar kemampuan daya tarik iklan dalam iklan "\#KerenLahirBatin". Sedangkan untuk daya tarik iklan yang tidak dijembatani keterlibatan responden hanya memiliki pengaruh sebesar $13,5 \%$ terhadap citra jenama Ramayana Department Store.

Daya tarik iklan hanya merupakan bagian kecil dari keseluruhan strategi pemasaran. Jika dikaitkan dengan tiga proses pembentukan citra jenama miliki Riezebos (2003: 66), selain melalui iklan, audiens juga bisa dengan mudah teralihkan atau terpengaruh oleh pengalaman mengonsumsi produk mereka sendiri dan pengaruh sosial, yakni opini orang-orang di sekitarnya. Kesan pertama suatu jenama cenderung melekat dalam diri audiens sehingga pengaruh komunikasi pemasaran dalam mengubah suatu citra tidaklah mudah, apalagi jika hanya dilihat dari pengaruh daya tarik iklan sendiri yang persentasenya lebih kecil dari pengaruh daya tarik iklan dan keterlibatan responden ( $16 \%>13,5 \%)$. Begitu juga dengan karakteristik generasi milenial sebagai responden yang berorientasi pada opini teman (peer review-oriented). Kecilnya persentase pengaruh tersebut dapat mengakibatkan persepsi responden yang sudah terbentuk di benak mereka setelah menonton iklan "\#KerenLahirBatin" dengan mudah dipengaruhi oleh cerita atau ulasan orang lain. Hal ini sejalan dengan hasil bahwa daya tarik iklan secara signifikan memengaruhi citra jenama, tetapi bersifat lemah.

Selain mengetahui pengaruh dari masing- 
masing kedua daya tarik iklan, pengaruh daya tarik rasional dan emosional ketika menjadi kesatuan juga diketahui melalui analisis jalur. Hasilnya, daya tarik iklan secara keseluruhan memiliki nilai pengaruh tidak langsung yang dijembatani keterlibatan responden terhadap citra jenama yang lebih besar dibandingkan nilai pengaruh langsung daya tarik iklan terhadap citra jenama yang tidak melibatkan keterlibatan responden. Ini artinya, daya tarik iklan akan jauh lebih mampu memengaruhi citra jenama jika responden ikut terlibat dalam pemrosesan informasi. Hal ini juga berbanding lurus dengan hasil sebelumnya, yang mana persentase pengaruh dari daya tarik iklan dan keterlibatan responden terhadap citra jenama yang lebih besar dibandingkan dengan persentase pengaruh daya tarik iklan terhadap citra jenama $(16 \%>13,5 \%)$. Jika keterlibatan responden (MOA) cenderung tinggi, maka kecenderungan elaborasi (EL) responden terhadap pesan pun tinggi. Kekuatan MOA dan EL responden ini mampu menentukan jenis proses pesan, yakni jalur sentral (central route) atau jalur periferal (peripheral route), yang nantinya memengaruhi sikap mereka mengenai jenama dalam iklan. Dengan mempertimbangkan keterlibatan audiens tersebut, pengiklan pun dapat menyusun strategi periklanan dengan daya tarik iklan yang lebih tepat dan efektif.

Guna melihat hubungan dan kecenderungan jawaban yang kemungkinan bisa menjadi faktor di balik alasan responden menjawab suatu pernyataan, dilakukan analisis tabulasi silang (crosstab) terhadap topik dan variabel yang memungkinkan dalam penelitian ini. Hubungan yang dikaji adalah perbedaan usia, jenis kelamin, profesi, dan durasi responden dengan keterlibatannya memproses iklan, serta perbedaan pengalaman dan profesi dengan pembentukan citra jenama.
Analisis ini menunjukkan terdapat dua dari enam hubungan di atas yang tidak berkorelasi meskipun jumlah dalam kategori ini hanya dua (perempuan-laki-laki/pernah-tidak pernah), yaitu jenis kelamin dan pengalaman berbelanja responden. Perbedaan jenis kelamin dilihat untuk membuktikan apakah terdapat daya tarik iklan tertentu yang dapat meningkatkan MOA pada responden laki-laki sedangkan perempuan tidak. Jawaban responden kedua jenis kelamin tidak jauh berbeda atau cenderung sama sehingga dapat disimpulkan perbedaan jenis kelamin tidak memengaruhi bagaimana daya tarik iklan meningkatkan MOA mereka. Begitu juga dengan responden yang pernah dan tidak penah berbelanja lebih dari sekali. Jawaban dari kedua perbedaan tersebut cenderung menunjukkan kesamaan sehingga perbedaan pengalaman tidak memengaruhi dan berhubungan dengan pembentukan citra jenama Ramayana Department Store. Padahal, peneliti memiliki asumsi awal bahwa responden yang pernah berbelanja lebih dari sekali bisa jadi memiliki citra jenama Ramayana yang lebih baik dibandingkan mereka yang tidak pernah.

\section{Kesimpulan}

Penelitian ini dilatarbelakangi oleh popularitas iklan Ramadan Ramayana "\#KerenLahirBatin" dan peran iklan dalam pembentukan brand image di benak audiens. Hasil dari penelitian menunjukkan pernyataan hipotesis yang diterima adalah adanya pengaruh daya tarik iklan terhadap brand image Ramayana Department Store, terbukti dari persentase pengaruh daya tarik iklan dan keterlibatan audiens terhadap brand image tersebut sebesar $16 \%$. Hasil tersebut sejalan dengan penelitianpenelitian sebelumnya yang menyatakan bahwa 
daya tarik iklan memiliki kontribusi pengaruh terhadap sikap yang timbul setelah menonton iklan. Selain itu, hasil penelitian juga mendukung pernyataan Hsu \& Hsu (2011: 4) dan Hyunjoo \& Jasper (2006: 17) bahwa ketika MOA audiens rendah, pemrosesan pesan tidak melalui proses kognitif dan hanya mengandalkan elemenelemen periferal, seperti penggunaan selebriti yang menarik, musik, humor, dan visual, agar terjadinya perubahan sikap yang bersifat sementara atau mempertahankan sikap awal audiens terhadap suatu produk/brand. Daya tarik emosional yang mendominasi pada iklan ini menyebabkan responden lebih diarahkan untuk memproses pesan melalui jalur periferal. Meskipun pengaruh yang timbul umumnya bersifat sementara, tetapi hasil brand image Ramayana yang terbentuk dalam diri generasi milenial sebagai responden dalam penelitian ini bersifat positif dan merupakan gabungan dari aspek fungsional maupun emosional yang diserap secara bersamaan. Hal tersebut pun sesuai dengan Meenaghan (1995: 7) yang menyatakan bahwa pembentukan brand image dalam diri audiens tidak hanya bergantung pada aspek emosional, tetapi juga melibatkan aspek fungsional dari sebuah produk/brand.

Hasil penelitian ini secara spesifik memperlihatkan bahwa pengaruh tidak langsung daya tarik iklan yang dijembatani keterlibatan audiens memproses iklan terhadap brand image Ramayana Department Store lebih besar dibandingkan pengaruh langsung daya tarik iklan terhadap brand image Ramayana Department Store. Ini artinya, keterlibatan audiens menjadi penting untuk dipertimbangkan agar pesan yang ingin disampaikan benar-benar dapat ditangkap dan dipahami oleh audiens sehingga sesuai dengan tujuan pengiklan. Daya tarik iklan akan jauh lebih mampu memengaruhi brand image jika responden ikut terlibat dalam pemrosesan pesan iklan. MOA dalam teori ELM ini membantu penelitian sebelumnya dalam mengungkapkan bagaimana elemen, termasuk daya tarik iklan, diproses pada jalur sentral atau jalur periferal. Dengan kata lain, peneliti dapat mengetahui bagaimana pengaruh elemen terhadap apa yang dikaji sekaligus elemen yang paling berpengaruh atau efektif, yakni daya tarik emosional seperti penggunaan jingle, unsur humor, unsur menyenangkan, ditambah popularitas iklan (viral).

Popularitas iklan "\#KerenLahirBatin" di berbagai media sosial berhasil meningkatkan kesadaran audiens pada brand Ramayana. Dari yang awalnya hanya sebatas konten milik akun Ramayana, kemudian iklan meluas menjadi bahan pembicaraan di media sosial. Popularitas iklan tersebut tentunya tidak lepas dari peran jari-jari pembagi konten, yakni audiens milenial sebagai responden penelitian ini. Hasil penelitian yang menunjukkan bahwa unsur daya tarik iklan, seperti penggunaan jingle, unsur humor, dan unsur menyenangkan paling berpengaruh bagi audien milenial sejalan dengan ketiga karakteristik milik Karpasitis (2017: 177) yang menyatakan bahwa visual, audio, dan alur cerita memiliki pengaruh dalam membuat iklan video menjadi viral. Generasi milenial memiliki kontrol dalam mengakses konten, dengan perangkat apa, di mana dan kapan saja mereka inginkan. Generasi milenial menyukai konten atau hiburan interaktif sehingga sebuah konten harus cukup menarik untuk bisa dijadikan bahan pembicaraan. Dengan populernya iklan "\#KerenLahirBatin", terutama dari elemen daya tarik emosional, membuktikan bahwa Ramayana telah menggunakan metode yang tepat dalam menjangkau milenial sebagai pengguna internet terbanyak di Indonesia.

Keterbatasan penelitian ini dapat dilihat 
dari beberapa hal. Pertama, data penelitian ini diperoleh dari sampel yang hanya berjumlah 100 responden. Suatu penelitian dengan menggunakan metode pengumpulan data survei akan lebih mampu mencapai keabsahan jika jumlah sampel semakin besar. Kedua, batas kesalahan penelitian turut menentukan jumlah sampel yang digunakan. Batas kesalahan yang diterapkan dalam penelitian ini adalah $10 \%$ atau 0,1 sehingga tingkat kepercayaan penelitian masih hanya sebesar $90 \%$. Oleh karena itu, akan lebih baik apabila pengkajian selanjutnya memperkecil persentase tersebut untuk memperoleh hasil penelitian yang lebih representatif dan kemungkinan jawaban yang lebih beragam. Ketiga, penelitian ini belum mampu menggali lebih mendalam mengenai seluk-beluk penerapan konsep daya tarik iklan dan pengaruh yang ditimbulkan melalui konsep jalur periferal dan jalur sentral dari teori ELM.

Penelitian ini hanya mampu memperoleh hasil yang masih berada di tingkat permukaan dan secara umum melihat kehadiran daya tarik iklan dan pengaruhnya terhadap brand image dari generasi milenial. Oleh karena itu, pengkajian yang lebih mendalam perlu dilakukan, termasuk kemungkinan bahwa daya tarik emosional yang mendominasi mampu menjadi layaknya elemen sentral yang kemudian dapat mengarahkan audiens untuk memproses pesan iklan produk pemenuhan kebutuhan berekspresi (busana) di jalur sentral, seperti pada penelitian Hyunjoo dan Jasper (2006) yang berjudul Processing of Apparel Advertisements: Application and Extension of Elaboration Likelihood Model. Keempat, penelitian ini pun belum mampu membuktikan apakah sikap atau brand image yang dipengaruhi oleh daya tarik iklan memang hanya bertahan sementara karena melalui jalur periferal. Akan lebih baik jika penelitian selanjutnya dapat sekaligus membuktikan daya tahan pengaruh yang timbul dari hasil pemrosesan pada jalur sentral atau jalur periferal.

Referensi

ADASSOC.org.uk. (n.d). What is Advertising?. Terarsi $\quad d$ a I a m https://www.adassoc.org.uk/advertisingsbig-questions/what-is-advertising/

Aaker, David A., \& Biel, Alexander L. (2009). Brand Equity \& Advertising: Advertising's Role in Building Strong Brands. New York: Psychology Press.

Akbari, Mahsa. (2015). Different Impacts of Advertising Appeals on Advertising Attitude for High and Low Involvement Products. Global Business Review, Vol. 16(3) 478-493.

Gould, Andrea M. (2014). Millennial Media Consumption and the Birth of the Anytime, Anywhere Television Viewing Experience. Thesis. Drexel University: Master of Science in Television Management.

Hyunjoo, Oh., \& Jasper, Cynthia R. (2006). Processing of Apparel Advertisements: Application and Extension of Elaboration Likelihood Model. International Textile \& Apparel Association Vol. 24, No. 1, hal. 1532.

Isoraite, M. (2018). Brand Image Development. Ecoforum Vol. 7, Issue 1(14).

Keller, Kevin L. (1993). Conceptualizing, Measuring, and Managing Customer-Based Brand Equity. Journal of Marketing, Vol. 57, No. 1 (Jan., 1993), hal. 1-22.

Khanna, P. (2016). A Content Analysis of Emotional and Rational Appeals in Selected Products Advertising. IRA-International Journal of Management \& Social Sciences Vol. 4(3), hal. 568-578. 
Kotler, P. \& Armstrong, G. (2012). Principle of Marketing. New Jersey: Prentice Hall

Kotler, P., \& Keller, Kevin L. (2012). Marketing Management, 14th ed. New Jersey: Prentice Hall.

Liputan6.com. (2018). Viral, Iklan Emak-Emak Kasidah Karya Dimas Djay Bikin Warganet $\mathrm{Ng}$ a k a k. Terars i p d a I a m https://www.liputan6.com/citizen6/read/3 528972/viral-iklan-emak-emak-kasidahkarya-dimas-djay-bikin-warganet-ngakak

Meenaghan, Tony. (1995). The Role of Advertising in Brand Image Development. Journal of Product \& Brand Management, Vol. 4 Issue: 4, hal.23-34.

Moreno, Flor M., Lafuente, Jaime G., Carreon, F. A., Moreno, S. M. (2017). The Characterization of The Millennials and Their Buying Behavior. International Journal of Marketing Studies, Vol. 9, No. 5, hal. 135144.

Moriarty, Sandra E. (1991). Creative Advertising, Theory and Practice. Englewood Cliffs, NJ: Prentice-Hall.

Pangerang, Andi M. K. (2018). Cerita di Balik Iklan Kocak Ramayana yang Viral. Terarsip dalam https://entertainment.kompas.com/read/ 2018/05/18/155157910/cerita-di-balikiklan-kocak-ramayana-yang-viral

Ramayana.co.id. (n.d). Company Profile $\mathrm{R}$ a maya $\mathrm{n}$ a. Terarsip dala $\mathrm{m}$ https://corporate.ramayana.co.id/index.ph p/en/about-the-company

Riezeboz, R. (2003). Brand Management: A theoretical and Practical Approach. Harlow: Pearson Education Limited.

Saputro, Wendiyanto. (2018). Toko Online Makin Ngetren, Ramayana Tetap Setia Main di Offline. Terarsip dalamhttps://kumparan. com/@kumparanbisnis/toko-online- makin-ngetren-ramayana-tetap-setiamain-di-offline

Sasetyo, Septa A., Nawawi, H., \& Rondonuwu, R. (2012). Pengaruh Daya Tarik Iklan terhadap Pembentukan Citra Merek Pepsodent. EJurnal Mahasiswa Universitas Padjadjaran Vol. 1., No.1. hal. 1-19.

Shimp, Terence A. (2003). Periklanan Promosi Aspek Tambahan Komunikasi Terpadu (Jilid 1). Jakarta: Penerbit Erlangga.

Sutisna. (2001). Perilaku Konsumen dan Komunikasi Pemasaran. Bandung: PT Remaja Rosdakarya.

Yordan, Jofie. (2018). Generasi Millenial Dominasi Pengguna Internet di Indonesia. Terarsip dalam https://kumparan.com/@kumparan tech/generasi-millenial-dominasipengguna-internet-di-indonesia 